\title{
Trans-boundary Movement of Hazardous Waste: Evidence from a New Micro Data in the European Union
}

\author{
Mahelet G. Fikru \\ Department of Economics, Missouri University of Science and Technology \\ $500 \mathrm{~W} 13^{\text {th }}$ St., Rolla MO 65409, USA \\ Tel: 11-1-573-341-6495_E-mail: fikruma@mst.edu
}

\author{
Received: December 9, 2011 \\ Accepted: January 13, 2012 Published: March 1, 2012 \\ doi:10.5539/res.v4n1p3 \\ URL: http://dx.doi.org/10.5539/res.v4n1p3
}

\begin{abstract}
The paper explores a new micro dataset on the export of hazardous waste generated in Europe. A total of 16745 industrial facilities generated hazardous waste in 2009 out of which 1272 exported some or all of the waste. A measure of the export intensity of facilities is introduced by using export of hazardous waste as a percentage of total hazardous waste generated. The study finds that $96 \%$ of the export stays within Europe and rarely goes to developing countries. The major driving force behind firms' decision to export hazardous waste may be the stringency of general environmental policies as well as the introduction of regulations and tax bases specific to waste disposal. Furthermore, the availability of sufficient waste management and recycling centers increases competition and decreases the cost of waste management, reducing the need to export hazardous wastes.
\end{abstract}

Keywords: Hazardous waste, Environmental policy, Waste handler, Trans-boundary movement, European Union, Waste management

\section{Introduction}

Economic growth and the rise in the production of goods and services leads to the creation of environmental 'bads' out of which hazardous wastes are the most dangerous for human health and the environment. Firms operating in advanced economies are required to reduce the release of hazardous wastes (Williams, 1987; Environmental Protection Agency [EPA], 2010). As a result several industrial facilities either recycle or recover hazardous wastes while others resort to treatment or disposal. Recycling, treatment and disposal is usually undertaken by a specialized agent which operates within the country. Other times, the waste is transported abroad for the purpose of disposal or recovery.

It is easy to find reports on the trans-boundary movement of hazardous wastes at the country level. For instance, the European Environmental Agency (EEA) reports the export and import of wastes in the European Union (EU). In addition, Eurostat, which is the European Commission's (EC) statistical database, reports data on total hazardous waste generated as well as total hazardous waste treated in all European countries, which can be used to approximate the net export (or import) of hazardous wastes. However, firm level data on the export of hazardous wastes is difficult to obtain.

With this in mind, the European parliament and the Council of the EU adopted the European Pollutant Release and Transfer Register (E-PRTR) in 2006 with the aim of providing transparent and accessible firm level data on industrial wastes. The E-PRTR is the first (and only) Europe-wide firm level database to directly report the amount of hazardous wastes industrial facilities ship to waste handlers inside and outside the country. All industrial facilities which transfer, to a third party, hazardous waste in excess of 2 tons per year are required to report the amount of hazardous waste transferred, the full address of the waste handler and report whether the waste is destined for disposal or recovery.

This study explores the new E-PRTR micro data to identify what type of industrial facilities export hazardous wastes, why they export and where the major destinations are. The study also introduces a measure of the 
export-intensity of firms and examines factors which affect the decision of individual firms to export hazardous waste.

An overview of the major hazardous waste generators in the EU is presented in Section 2. A measure of the export intensity of firms is proposed in Section 2.1 and destination countries are identified as importing countries in Section 2.2. In Section 3 possible factors that influence a firm's decision to export hazardous waste are explored.

\section{Overview of Data}

The E-PRTR provides firm-level environmental data (release of pollutants to air, water and land as well as pollutants and waste transferred to other facilities for treatment) for over 28000 industrial facilities operating in the EU, Norway, Iceland, Switzerland and Liechtenstein for the years 2007, 2008 and 2009. The facilities are engaged in activities which typically release pollutants harmful for human health and the environment. Data is maintained by the European Environmental Agency (EEA) and can be accessed at http://prtr.ec.europa.eu/.

This study uses the E-PRTR to identify a total of 16745 industrial facilities which generated hazardous waste in 2009. Out of these, 1272 exported some or all of the waste for the purpose of disposal or recovery. The remaining 15473 facilities transferred all hazardous waste to local waste handlers.

In Section 2.1, facilities engaged in the trans-boundary transfer of hazardous waste are identified as 'exporters' and a measure of the export-intensity of firms is introduced. Section 2.1 also discusses why the export intensity measure is preferred compared to other commonly used measures. In Section 2.2, destination countries are identified as 'importers' and import intensity is measured at the country-level to represent a country's demand for hazardous waste.

\subsection{Export intensity}

The study is based on a sample of industrial facilities which generated hazardous wastes in 30 European countries in the year 2009. A total of 16745 facilities generated hazardous wastes in 2009 out of which 1272 have exported some or all of the hazardous waste. These facilities operate in the EU-27, Norway, Iceland and Switzerland. The total amount of hazardous waste generated in 2009 is close to 40.3 million tons out of which $11.35 \%$ (or 4.5 million tons) is exported. Exported waste is destined for either recovery or disposal (European Commission [EC], 2006a).

To study what factors affect a firm's decision to export hazardous waste, one needs to measure the export decision of hazardous waste producers. Such a measure should represent the allocation decision of hazardous waste producers; that is, what drives a firm to export hazardous waste as opposed to using local waste management options. An appropriate measure should control for country and firm size effects.

This paper introduces a measure of export intensity of firms as the ratio of amount exported to amount generated. The total waste generated by a facility is calculated by summing hazardous waste exported and hazardous waste treated by local agents within the country (Note 1). Export intensity measures the percentage of hazardous waste exported per total hazardous waste generated by a facility. This measure helps to perform appropriate comparative analysis which would be impossible by using the total amount exported. Bigger firms (or countries with large number of industrial facilities) may have higher gross export due to their bigger sizes and hence gross export does not control for firm size and number of firms in a country.

Using the export-intensity measure has advantages over using Eurostat's measure of net export, which is the difference between total hazardous waste generated and total hazardous waste treated. Bigger countries and countries with large number of facilities may have high positive net exports and Eurostat's measure of net export does not control for country size. In addition, the export intensity measure has advantages over using the share of a firm's export in national export since shares do not control for firm size effects and fail to reveal the percentage of waste a firm exports as opposed to using local waste management options.

The EEA uses gross export of hazardous waste per capita to rank waste exporters in the EU (European Environmental Agency [EEA] Report, 2009). This measure controls for the size of a country, however, it does not reveal the tendency to export and it does not take into account the number and size of hazardous waste producers. The normalization technique suggested in this paper indicates that the choice of an appropriate measure is essential for understanding the characteristics, behavior and choice of individual firms.

Table 1 ranks hazardous waste producers based on their export intensity. Out of the 1272 firms which exported hazardous waste in 2009 , close to $40 \%$ have exported more than $50 \%$ of the hazardous waste they generated.

All hazardous waste producers are required to report whether hazardous wastes are destined for recovery or for 
disposal. Accordingly, about $60 \%$ of the export is destined for recovery whereas the rest is destined for disposal. On the contrary, about $45 \%$ of hazardous waste treated by domestic waste handlers is destined for recovery while the rest is destined for disposal. A lower percentage of export destined for disposal may be caused by two factors. First of all, EU's approach to regulate the shipment of hazardous waste for disposal with more restrictions as compared to shipments for recovery may increase the cost of exports destined for disposal. Secondly, with the development of better recycling facilities importing countries can convert hazardous wastes to usable secondary raw materials and/or recover energy. As a result importing countries may have a higher demand for the recovery of wastes as compared to wastes destined for disposal.

A larger portion of hazardous waste treated locally is disposed (55\%). This may be caused by inadequate recycling and recovery centers at home. If countries have their own recycling and recovery centers, the need to export hazardous waste for recovery may decline. Furthermore, countries with a relatively large waste management industry can offer services cheaply through improved competition and thus firms operating in such countries may view export as an expensive option. Section 3 presents a test for whether the decision of firms to export hazardous waste is affected by the availability of local recycling and waste management centers.

Countries which export hazardous waste can be ranked based on their export intensity. As Table 2 indicates, small countries such as Ireland, Slovenia, Lithuania and Latvia are ranked first in export intensity followed by Iceland, UK, Switzerland and Austria. Countries like Hungary, Romania, Spain, Greece and Estonia have export intensities lower than 1\%. The bigger EU Member States such as France and Germany also have lower export intensities (less than 7\%) even though these countries are among the top 10 largest exporters in gross amount. Also note that France has the largest number of exporters (295) followed by Belgium (150) and Ireland (145). France also has the second highest number of hazardous waste producers (2 347). However, France exported only $7 \%$ of total hazardous waste generated in 2009 .

The 16745 hazardous waste producers are engaged in 9 different types of industrial activities. Table 3 presents the export intensity of these activities. The production of animal and vegetable products as food and beverage has the highest gross export as well as the highest export intensity even though the number of exporters is only 35. These are either slaughterhouses or animal and vegetable treatment and processing centers. The waste and wastewater management sector exported about 1.8 million tons of hazardous waste and this represents only $8.6 \%$ of total hazardous waste generated. This indicates that the sector either transfers its waste to other treatment facilities within the country or undertakes treatment on-site.

The above discussion illustrates that export intensity yields an appropriate ranking of hazardous waste exporters which is not affected by size or number of firms but only capturing information on the tendency to export than using domestic options. Following, in Section 2.2, the destinations of the export of hazardous waste originating from the 30 European countries are identified.

\subsection{Importing countries}

The E-PRTR requires all hazardous waste exporters to report the destination of the waste and the full address of the waste handler. There are 32 importing countries (or destinations) out of which 24 are European countries, 6 are developing countries and the rest are Canada and the United States. The 24 European importers are countries presented in Table 2 with the exception of Cyprus, Greece, Iceland, Malta, Romania and Slovenia. Table 4 presents the destination of hazardous waste and amount of waste imported in 2009.

Even though scholars, policy makers and environmentalist give significant attention to the export of wastes to poor countries (Ibitayo, 2008; Clapp, 2001) about 95.7\% of the export of hazardous waste from the EU goes to Member States. The large share of trade in hazardous waste among EU Member States is mainly due to Regulation (EC) No. 1013/2006 (also known as Waste Shipment Regulation) which prohibits the export of hazardous wastes to non-OECD countries (EC, 2006b). Baggs (2009) explains that the major reason behind the trade direction is that richer countries have higher capital to worker ratio and thus better availability of disposal facilities. Consistent with this, Murphy (1994) found that European countries export six times higher hazardous wastes to each other than to developing countries.

About $4 \%$ of the hazardous waste is exported to confidential destination sites where the destination country and address of the waste handler are not reported. The waste originated from 109 industrial facilities in Belgium (export of 186818 tons) and 10 facilities in Luxembourg (export of 2965 tons). From the 189783 tons of export to confidential sites, $64 \%$ is from the waste and wastewater management sector, $25 \%$ is from the chemical industry, $5 \%$ from the energy sector and $5 \%$ from processing and production of metals.

Another 4 facilities in Sweden exported hazardous waste to Germany and Denmark but did not disclose the 
amount exported. According to the E-PRTR guidance document, individual facilities may keep some data confidential, however they are required to report what type of information is withheld and why. Accordingly, all facilities have reported the reason for confidentiality as being consistent with Article 4(2)(d) of Directive 2003/4/EC which states that firms may refuse disclosure of information if disclosure would adversely affect the "confidentiality of commercial or industrial information where such confidentiality is provided for by national or Community law to protect a legitimate economic interest, including the public interest in maintaining statistical confidentiality and tax secrecy" (EC, 2006a). In addition, sovereign countries may request confidentiality on some data if disclosure compromises national security, justice, public interest, intellectual property rights, the protection of the environment etc.

For the $24 \mathrm{EU}$ importers, the import intensity of countries is measured by taking the ratio of amount of hazardous waste imported to total hazardous waste generated in the country. This measure indicates the demand for import for each unit of hazardous waste generated locally. Gross import does not control for country-size effects and would not be appropriate for comparative studies. For instance, in 2001 the United Nations Environmental Program (UNPEP) ranked Germany as the highest importer of hazardous waste in Europe (where waste originated in Netherlands, Italy, Belgium and Luxembourg) based on gross imports of over 1 million tons (UNEP, 2004). Data from the E-PRTR indicates that in 2009, Germany imported 1356460 tons of hazardous waste which represents only $11.5 \%$ of total hazardous waste generated in the country. Gross import does not control for number and size of firms nor does it capture the demand for imports. Rather import intensity can better be used to normalize fluctuations in economic activity and reveal the demand for the import of hazardous wastes.

Belgium has the highest import intensity of over $100 \%$ followed by Austria (22\%), Denmark (19\%), Norway $(15 \%)$, Lithuania (12\%), Germany (11\%), Sweden (8\%), France (7\%), Latvia (4\%) and Netherlands (4\%). Countries like Spain, Switzerland, Luxembourg and Poland have import intensity between 1-4\%. Countries like the UK, Hungary, Ireland, Slovakia, Finland, Estonia, Portugal, Czech Republic, Bulgaria and Italy have import intensity less than $1 \%$.

So far, we have introduced a measure of export intensity of industrial facilities and discussed major importing countries. In Section 3 we discuss factors which affect a firm's decision to export hazardous waste. The purpose is not to come up with an exhaustive list of why firms export waste. Rather, the purpose is to illustrate how the E-PRTR data and the export intensity measure can be applied in economic analysis.

\section{Why Industrial Facilities Export Hazardous Waste}

The two most commonly cited reasons for the export of wastes is the effect of environmental policies and the price of waste disposal and recovery. First of all, the hotly debated pollution haven hypothesis predicts that lax environmental policies attract investment from polluting industries as well as promote export of pollution-intensive goods (Cole, 2004; Cave and Blomquist, 2007). Reports of the European Environmental Agency (EEA Report, 2009) indicate that countries with low or no national waste tax tend to import hazardous waste from countries with higher waste tax. In addition, the stringency and enforceability of environmental regulations may increase the cost of waste management. Section 3.1 examines three types of policy instruments: general environmental policies, policies specific to waste management and narrower policies specific to hazardous waste. In Section 3.3 the export intensity measure of industrial facilities is used to illustrate how the E-PRTR can be used in testing the implications of the pollution haven hypothesis.

Secondly, the main driving force for the export of hazardous waste is the cost of waste disposal and recovery and the difference in the price of waste management in different countries (EEA Report, 2009). As discussed in Section $2.1,60 \%$ of the exported waste is destined for recovery whereas only $45 \%$ of the locally treated waste is recovered. The implication may be that countries with a large waste management and recycling market provide services cheaply by competing for usable secondary raw materials or recovered energy. As a result, firms in such countries may have a lower export intensity. Furthermore, exporting countries may have insufficient technological capability to manage wastes which require specialized technology found only in physically and economically larger countries. Section 3.2 reviews the number of recycling and waste management centers in the EU. Section 3.3 presents an empirical test to determine the relative significance of environmental policies and number of waste management and recycling centers in affecting the export decision of industrial facilities.

\subsection{Environmental policy}

In the EU, there are several policy instruments used to address waste management. The Organization of Economic Cooperation and Development in collaboration with the European Environmental Agency (OECD/EEA) has constructed an online database on all environmentally related taxes, fees and charges used to 
address waste management in the OECD and the EU. For each country, data is sorted first by the type of regulation used for waste management where the name of each regulation is given along with the year of introduction. The number of regulations is used to test whether waste management regulations affect the decision of industrial facilities to export hazardous waste.

Further, under each regulation, there are several tax-bases. For instance, in 1990 Austria introduced a waste deposit levy under which there are 5 tax bases namely; deposition of materials in landfills approved for dangerous waste, construction waste, residual materials, biodegradable waste and waste incineration. Similarly, in 1996 UK introduced a landfill regulation based on 2 bases; a standard rate and a different rate for inert wastes. Likewise, the rest of the countries have regulations and tax bases pertaining to waste disposal. Table 5 provides a summary of the number of regulations and number of tax bases in the EU. Given a particular regulation, expansion of the tax base may affect a firm's decision to export hazardous waste and thus we use the number of tax bases to control for this effect.

Almost all of the regulations and tax bases focus on discouraging waste disposal. Table 6 shows that firms which operate in countries with the highest number of regulations (more than 7) on waste disposal, on average, have a significantly higher export intensity compared to firms which operate in countries with less than 8 regulations. In addition, facilities which operate in countries with the lowest number of regulations on waste disposal (only 1) have significantly lower export intensity as compared to firms which operate in countries with more than one regulation. Regulation on waste disposal increases the cost of waste disposal; as a result firms seek to transfer waste to other countries.

The relationship between the number of tax bases and the average export intensity of firms shows a similar trend. Firms which operate in countries with number of tax bases higher than the EU average (EU average is 18) have a significantly higher export intensity compared to firms which operate in countries with fewer tax bases than the EU average.

In addition to the effect of regulations pertaining specifically to waste disposal, the general stringency of environmental policies as well as enforceability may affect a firm's decision to allocate hazardous wastes to local and foreign waste handlers. Countries that raise large tax revenue from environmental sources usually are (or try to be) "greener" as environmental taxes become a major source of government revenue. Eurostat provides historical data on the amount of revenue collected from environmental taxes in the EU (Note 2). A high share of environmental taxes from total revenue indicates that countries have stringent and/or effectively enforced policy. On average about $7.3 \%$ of government revenue is collected from environmental taxes in the EU (see Table 7). Countries like Netherlands, Bulgaria, Malta, Denmark and Slovenia have the highest share of environmental taxes from total revenue whereas Iceland and Belgium have the lowest share of environmental taxes from total revenue.

Using data from the 1272 hazardous waste exporters we find a positive correlation (correlation coefficient of 0.282) between environmental taxes as a percentage of revenue and export intensity. Firms which operate in countries which raise a larger percentage of revenue from environmental taxes seem to export a larger percentage of hazardous waste generated. This indicates that in addition to policies specific to waste management, the general environmental policy framework including enforceability may affect a firm's decision to export.

Lastly, we consider narrower policies pertaining specifically to hazardous waste management. Twelve of the countries in our sample have a tax, charge or fee levied directly on the collection, management and disposal of hazardous wastes. Data is obtained from the OECD/EEA and Table 8 summarizes these instruments. A total of 4 503 firms operate in countries with some form of policy regulating the collection, treatment and disposal of hazardous waste. These firms export on average $2.14 \%$ of hazardous waste generated whereas firms operating in countries without such policies have a significantly higher average export intensity of $3.72 \%$. Perhaps the existence of hazardous waste policy operates by reducing the incentives to collect, ship and transport hazardous waste.

\subsection{Market for waste management and recycling}

The structure of the market for waste management and recycling has implications on the cost of disposal and recovery. When the waste management and recycling market is concentrated with few waste handlers, existing agents have market power to raise prices. Hence, firms find it expensive to use domestic waste management options and may export their wastes to countries where the market is less concentrated and the cost of waste management is low.

Eurostat provides a year-by-year data on the number of waste management and recycling enterprises in all 
European countries. The 30 countries had a total of 43870 waste management and recycling enterprises in 2009 . The market share of each country's waste management and recycling is calculated by taking the number of enterprises in each country over the total 43870 expressed as a percentage. France (24\%), UK (15\%) and Poland (11\%) own (or are hosts to) about $50 \%$ of the waste management and recycling centers in the EU. Countries like Ireland, Denmark, Slovenia, Slovakia, Lithuania, Netherlands, Luxembourg, Latvia and Estonia each own less than $1 \%$ of the waste management and recycling centers and together account for $5 \%$ of the market. The argument is that countries which have a high share of waste management and recycling facilities have lower export intensity since they choose the cheaper local waste management centers.

\subsection{Empirical test}

In this section, we present empirical tests from simple econometric regressions to illustrate a possible use of the E-PRTR database and the export intensity measure in economic analysis. We test for the effect of environmental policy and the market for waste management and recycling on the export intensity of industrial facilities in the EU. We control for four types of policy instruments: stringency and enforceability of general environmental policy as measured by the share of environmental tax from total revenue, number of regulations on waste disposal, number of tax bases on waste disposal and narrower policies on hazardous waste management. The effect of policies specific to hazardous waste is controlled for by using country dummies for the 12 countries reported in Table 8 . In addition to testing for the effect of the 4 policy instruments separately, an interaction term is used to test for the effect of a combination of the first three policy variables. The share of a country's waste management and recycling market in the $\mathrm{EU}$ is used to control for the cost of waste management.

In addition, the standard of living in a country may affect the export decision of industrial facilities where countries with a higher living standard generally have a higher demand for environmental quality. Given high demand for environmental quality, industrial facilities may choose the most environmentally friendly waste management option. GDP per capita of countries is used to control for this effect. Table 9 presents a descriptive statistics of the variables under study.

Since export intensity of firms is a bounded variable, the primary model used to fit the data is a censored regression. We also present a Probit model which does not account for the variation in the export intensity of exporter but assigns a value 1 to the 1272 waste exporters and 0 otherwise. The empirical test is based on the 16 745 hazardous waste producers and results are presented in Table 10. Model (a) controls for the effect of the cost of waste management and living standards. Model (b) controls for the effect of the 4 policy instruments (country dummies not presented for brevity). Model (c) controls for the effect of the 4 policies and the cost of waste management. Model (d) adds an interaction term between the number of regulations, the number of tax bases and the percentage of environmental taxes from total revenue. Finally, Model ( e) presents results from a Probit model.

The statistical result shows that keeping other factors constant the two policy instruments, namely total number of regulations and total number of tax bases, have a significantly positive effect on the export intensity of firms. Similarly, the stringency and enforceability of general environmental policies has a positive significant effect on the export decision of industrial facilities. In addition, a combination of the three policy instruments (number of regulation, number of bases, environmental tax) yields significantly higher export intensity for individual firms. Firms which operate in countries with a large market share of waste management and recycling have significantly lower export intensity as they seek cheaper domestic options rather than exporting.

Out of the 12 countries which have a hazardous waste policy, only Denmark and Belgium have a significantly higher coefficient. The coefficients for Czech, Hungary, Portugal, Slovakia and Spain are significantly negative. This indicates that narrower policies specific to hazardous waste management may not be as important as the general environmental policy framework, regulations on waste disposal and tax bases in these countries.

\section{Conclusion}

The paper explores a new micro dataset on the export of hazardous waste generated from industrial facilities operating in Europe. A measure of the export intensity of firms is introduced by using the amount of export of hazardous waste as a percentage of total hazardous waste generated. Small countries such as Ireland, Slovenia, Lithuania and Latvia rank as the largest exporters of hazardous waste compared to total hazardous waste generated locally. We also find that the production and processing of animal and vegetable products (as food and beverage) has the highest export intensity from all sectors. In addition, about $40 \%$ of hazardous waste exporters exported over $50 \%$ of hazardous wastes they generated where $96 \%$ of the total export stayed within Europe. Countries such as Belgium, Austria, Denmark, Norway and Lithuania have the highest demand for the import of hazardous waste. 
A closer look at the micro evidence helps to formulate hypotheses that explain why firms decide to export waste. We find that the major driving force behind firms' decision to export hazardous waste may be the stringency of general environmental policies as well as the introduction of regulations and tax bases specific to waste disposal. Furthermore, the availability of sufficient waste management and recycling centers increases competition and decreases the cost of waste management, reducing the need to export wastes.

The E-PRTR dataset is the primary source of information on the export of hazardous waste from industrial facilities operating in the EU. However, the Register needs to be well developed to provide a complete data on the movement of hazardous waste. As it is now, the E-PRTR fails to provide information on whether facilities undertake on-site treatment of hazardous waste (storing, disposal or recovery). In the future, data collection can easily be improved by providing questions pertaining to on-site treatment of wastes and open-ended questions on how firms view the national waste policy.

\section{References}

Baggs, J. (2009). International Trade in Hazardous Waste. Review of International Economics, 17 (1), 1-16. http://dx.doi.org/10.1111/j.1467-9396.2008.00778.x

Cave, L. A. \& Blomquist, G. C. (2008). Environmental Policy in European Union: Fostering the Development of Pollution Havens. Ecological Economics, 56, 253-261. http://dx.doi.org/10.1016/j.ecolecon.2007.12.018

Clapp, J. (2001). Toxic Export: The Transfer of Hazardous Waste from Rich to Poor Countries. Ithaca, NY: Cornell University Press.

Cole, M. A. (2004). Trade, the Pollution Haven Hypothesis and the Environmental Kuznets Curve: Examining the Linkages. Ecological Economics, 48, 71-81. http://dx.doi.org/10.1016/j.ecolecon.2003.09.007

EC (2001). Environmental Taxes - A Statistical Guide. [Online] Available: http://epp.eurostat.ec.europa.eu/portal /page/portal/environmental_accounts/documents/2.pdf

EC (2006a). Guidance Document for the Implementation of the European PRTR. [Online] Available: http://prtr. ec.europa.eu/docs/EN_E-PRTR_fin.pdf

EC (2006b). Regulation of the European Parliament and the Council. Shipments of Waste. Official Journal of the European Union, (EC) No. 1013/2006.

EEA Report (2009). Waste without Borders in the EU? Trans-boundary Shipments of Waste. EEA Report No.1, Copenhagen.

EPA (2010). United States Takes Action to Reduce Hazards from Fertilizer Manufacturing Plant in Florida First Enforcement Case Concluded Against Mining and Mineral Processing Industry. [Online] Available: http://yosemite.epa.gov/opa/admpress.nsf/3ee0a48cce87f7ca85257359003f533d/7826d13e033a1 cac8525777a00 6bfa26!OpenDocument

Ibitayo, O. \& Burns, W. C. G. (2008). Trans-boundary Dumping of Hazardous Waste. In C. J. Cleveland, Encyclopedia of Earth (Eds.). Washington D.C.: Environmental Information Coalition. National Council for Science and the Environment.

Murphy, S. D. (1994). Prospective Liability for the Trans-boundary Movements of Hazardous Wastes. American Journal of International Law, 88 (1), 24-52.

UNEP (2004). Vital Waste Graphics. [Online] Available: http://www.grida.no/publications/vg/waste/

Williams, A. C. (1987). A Study of Hazardous Waste Minimization in Europe: Public and Private Strategies to Reduce Production of Hazardous Waste. Boston College Environmental Affairs Law Review, 14 B.C, 165-255.

\section{Notes}

Note 1. The E-PRTR does not require firms to report the amount of hazardous waste stored, disposed and/or recovered within the reporting facility (if any). This may lead to a possible bias in the calculation of total hazardous waste generated.

Note 2. Environmental tax (excludes charges and fees) is any tax whose base is a physical unit (or a proxy of it) of something that has a proven, specific negative impact on the environment. It is collected from energy (including $\mathrm{CO}_{2}$ taxes, coke, coal, biofuels, electricity, petrol, diesel, natural gas, fuel oil etc.), transport (registration of vehicles, sales taxes and tax on other transport services), pollution (emissions to air and water, certain non-point source water pollution, ozone depleting substances, waste management and noise) and resources (oil, gas, mining, extraction of raw materials, forests and water (EC, 2001). 
Table 1. Export intensity of industrial facilities (2009)

\begin{tabular}{|c|c|}
\hline Export Intensity (\%) & Number of Firms \\
\hline $0 \%$ & 15473 \\
\hline $0-50 \%$ & 763 \\
\hline $50-75 \%$ & 141 \\
\hline $75-99 \%$ & 249 \\
\hline $100 \%$ & 119 \\
\hline Total & 16745 \\
\hline
\end{tabular}

Table 2. Hazardous waste exporters in the EU (2009)

\begin{tabular}{|c|c|c|c|c|}
\hline Country & $\begin{array}{c}\text { Number of hazardous } \\
\text { waste } \\
\text { producers }\end{array}$ & $\begin{array}{c}\text { Number of } \\
\text { hazardous waste } \\
\text { exporters }\end{array}$ & $\begin{array}{l}\text { Gross export } \\
\text { (ton) }\end{array}$ & $\begin{array}{c}\text { Export intensity } \\
(\%)\end{array}$ \\
\hline Austria & 111 & 18 & 71736.1 & 27.57 \\
\hline Belgium & 723 & 150 & 279230.7 & 17.47 \\
\hline Bulgaria & 57 & 5 & 1975 & 2.58 \\
\hline Cyprus & 11 & - & - & - \\
\hline Czech Rep. & 560 & 12 & 6366.5 & 1.20 \\
\hline Denmark & 173 & 20 & 69104.9 & 16.93 \\
\hline Estonia & 73 & 9 & 878.02 & 0.11 \\
\hline Finland & 338 & - & - & - \\
\hline France & 2347 & 295 & 184331.5 & 6.97 \\
\hline Germany & 3353 & 86 & 132086.8 & 1.12 \\
\hline Greece & 86 & 7 & 4614.4 & 0.56 \\
\hline Hungary & 306 & 6 & 684.6 & 0.33 \\
\hline Iceland & 3 & 1 & 5170 & 32.87 \\
\hline Ireland & 208 & 145 & 145958.6 & 80.47 \\
\hline Italy & 1796 & 111 & 744771.32 & 16.40 \\
\hline Latvia & 18 & 1 & 1890 & 36.66 \\
\hline Lithuania & 40 & 4 & 9393 & 54.77 \\
\hline Luxembourg & 24 & 11 & 27541.4 & 26.52 \\
\hline Malta & 9 & 4 & 987 & 7.83 \\
\hline Netherlands & 535 & 114 & 413411.6 & 9.69 \\
\hline Norway & 168 & 23 & 94444.6 & 11.62 \\
\hline Poland & 749 & 15 & 17495.6 & 2.53 \\
\hline Portugal & 341 & 16 & 43829.9 & 20.76 \\
\hline Romania & 112 & 2 & 78.04 & 0.03 \\
\hline Slovakia & 224 & 7 & 4814.9 & 4.68 \\
\hline Slovenia & 114 & 54 & 39830.5 & 65.48 \\
\hline Spain & 1687 & 23 & 10774.5 & 0.57 \\
\hline Sweden & 421 & 42 & 122073.8 & 23.37 \\
\hline Switzerland & 183 & 35 & 156342.02 & 27.80 \\
\hline UK & 1983 & 56 & 1988249.8 & 32.25 \\
\hline Total & 16745 & 1272 & 4578064.04 & 11.35 \\
\hline
\end{tabular}


Table 3. Hazardous waste exporters by sector (2009)

\begin{tabular}{|l|l|l|l|}
\hline Activity & $\begin{array}{l}\text { Gross export } \\
\text { (ton) }\end{array}$ & $\begin{array}{l}\text { Number of } \\
\text { exporters }\end{array}$ & $\begin{array}{l}\text { Export intensity } \\
(\%)\end{array}$ \\
\hline Paper \& wood production & 593.23 & 18 & 0.29 \\
\hline Other activities & 13497.7 & 49 & 1.27 \\
\hline Mineral industry & 4767.2 & 59 & 1.54 \\
\hline Energy sector & 69323.5 & 80 & 2.42 \\
\hline Chemical industry & 270249.3 & 311 & 4.54 \\
\hline Production \& processing of metals & 521900.7 & 327 & 7.48 \\
\hline Waste \& wastewater management & 1782252.4 & 390 & 8.57 \\
\hline Intensive livestock \& aquaculture & 755.50 & 3 & 9.66 \\
\hline Animal \& vegetable products (food \& beverage) & 1924635.5 & 35 & 88.44 \\
\hline & & & \\
\hline
\end{tabular}

Table 4. Destination of hazardous waste (2009)

\begin{tabular}{|c|c|}
\hline Waste handler operates in & Gross import (ton) \\
\hline 24 EU & 4384108 \\
\hline USA & 298 \\
\hline Canada & 2.63 \\
\hline China & 595 \\
\hline Afghanistan & 66 \\
\hline Morocco & 29 \\
\hline Antigua \& Barbuda & 3 \\
\hline Korea & 31 \\
\hline Andorra & 3150 \\
\hline Confidential & 189783 \\
\hline Total & 4578065 \\
\hline
\end{tabular}


Table 5. Number of regulations and tax bases

\begin{tabular}{|c|c|c|c|c|c|}
\hline Country & Regulation & Tax base & Country & Regulation & Tax base \\
\hline Denmark & 9 & 83 & Estonia & 3 & 32 \\
\hline Finland & 8 & 14 & Lithuania & 3 & 20 \\
\hline Hungary & 8 & 31 & Poland & 3 & 14 \\
\hline Slovenia & 8 & 9 & Romania & 3 & 10 \\
\hline Italy & 7 & 24 & Slovakia & 3 & 17 \\
\hline Portugal & 7 & 28 & France & 2 & 7 \\
\hline Belgium & 5 & 40 & Germany & 2 & 9 \\
\hline Sweden & 5 & 10 & Iceland & 2 & 27 \\
\hline Switzerland & 5 & 19 & Ireland & 2 & 3 \\
\hline Czech Rep. & 4 & 9 & Malta & 2 & 8 \\
\hline Latvia & 4 & 20 & Netherlands & 2 & 9 \\
\hline Norway & 4 & 8 & Austria & 1 & 5 \\
\hline Spain & 4 & 13 & Greece & 1 & 1 \\
\hline Bulgaria & 3 & 38 & UK & 1 & 2 \\
\hline \multicolumn{7}{|l|}{} \\
\hline \multicolumn{7}{|l|}{ No information available for Cyprus and Luxembourg } \\
\hline
\end{tabular}

Table 6. Mean estimation

\begin{tabular}{|c|c|c|}
\hline Number of regulations & Export intensity (firm-level mean) & Standard error \\
\hline 1 & $0.145^{+}$ & 0.0022 \\
\hline 2 & $0.043^{*}$ & 0.0021 \\
\hline 3 & $0.159^{+}$ & 0.0031 \\
\hline 4 & $0.076^{+}$ & 0.0014 \\
\hline 5 & $0.0717^{*}$ & 0.0060 \\
\hline 7 & 0.0257 & 0.0028 \\
\hline 8 & $0.047^{*}$ & 0.0067 \\
\hline 9 & $0.061^{*}$ & 0.0170 \\
\hline Number of tax bases & Export intensity (firm-level mean) & Standard error \\
\hline Tax base $>18$ & $0.0421^{*}$ & 0.0367 \\
\hline Tax base $<18$ & 0.0303 & 0.0277 \\
\hline \multicolumn{3}{|c|}{ *Mean significantly higher than lower number of regulations at $1 \%$ level } \\
\hline \multicolumn{3}{|c|}{${ }^{+}$Mean significantly lower than higher number of regulations at $1 \%$ level } \\
\hline Mean significantly higher $\mathrm{t}$ & ax base at $1 \%$ level & \\
\hline
\end{tabular}


Table 7. Environmental tax in the EU

\begin{tabular}{|ccccc|}
\hline \multicolumn{5}{c|}{ Environmental tax as a percentage of revenue } \\
\hline$>9 \%$ & $8 \%-9 \%$ & $6.5 \%-8 \%$ & $5 \%-6.5 \%$ & $<5 \%$ \\
\hline Netherlands & Poland & Greece & France & Iceland \\
Bulgaria & Portugal & Norway & Spain & Belgium \\
Malta & Cyprus & Luxembourg & Austria & \\
Denmark & Estonia & Hungary & Germany & \\
Slovenia & Ireland & Slovakia & Sweden & \\
& Latvia & Lithuania & Italy & \\
& & Romania & Finland & \\
& & Czech Rep. & & \\
& & & & \\
& & &
\end{tabular}

Table 8. Policies regulating hazardous waste management

\begin{tabular}{|ll|}
\hline Country & Regulation on hazardous waste (Year of introduction) \\
\hline Belgium & Tax on hazardous waste collection (1991) \\
Czech Rep. & Fines for violation of regulations on hazardous waste collection, trade and \\
Denmark & labeling (1997) \\
Estonia & Hazardous waste deposit and disposal fee and charge (1991/2) \\
& Charge on hazardous waste \\
Finland & Waste disposal charge (1991) and non-compliance fee for disposal without \\
Hungary & permit or over allowed amount (1994) \\
Iceland & Charge on hazardous waste (1984) \\
Latvia & Charge on hazardous waste \\
Portugal & Hazardous waste fee (1997) \\
& Hazardous waste disposal charge (1995) \\
Slovakia & Waste management/disposal tax in Integrated Recovery (2007) and \\
Spain & Disposal of Hazardous Waste Centers landfill (CIRVER) \\
\hline
\end{tabular}


Table 9. Descriptive statistics

\begin{tabular}{|c|c|c|c|c|c|}
\hline Variables & Obs. & Mean & Std. & Min & Max \\
\hline Gross export (ton) & 16745 & 273.99 & 14832.5 & 0 & $1.9 \mathrm{~m}$ \\
\hline Total hazardous waste generated (ton) & 16745 & 2409.7 & 28501.51 & 2 & $2.2 \mathrm{~m}$ \\
\hline Export intensity (\%) & 16745 & 0.0329 & 0.1540 & 0 & 1 \\
\hline Number of tax base & $28^{*}$ & 18.214 & 16.631 & 1 & 83 \\
\hline Number of instrument & $28^{*}$ & 3.964 & 2.364 & 1 & 9 \\
\hline Environmental tax (\% revenue) & $29^{+}$ & 7.270 & 1.682 & 4.6 & 10.48 \\
\hline Hazardous waste tax dummy & 30 & 0.4 & 0.498 & 0 & 1 \\
\hline Share of waste management \& recycling (\%) & $24^{\ddagger}$ & 3.63 & 5.68 & 0.13 & 23.59 \\
\hline \multicolumn{2}{|c|}{ GDP per capita (\$10 000) } \\
\hline " Luxembourg \& Cyprus missing; ${ }^{+}$Switzerland missing; ${ }^{\star}$ Greece, Iceland, Italy, Malta, Netherlands \& \\
\hline
\end{tabular}

Table 10. Empirical test

\begin{tabular}{|c|c|c|c|c|c|}
\hline \multicolumn{6}{|c|}{ Dependent variable: Export intensity of firms } \\
\hline & $\begin{array}{l}\text { Tobit } \\
\text { (a) }\end{array}$ & $\begin{array}{l}\text { Tobit } \\
\text { (b) }\end{array}$ & $\begin{array}{l}\text { Tobit } \\
\text { (c) }\end{array}$ & $\begin{array}{l}\text { Tobit } \\
\text { (d) }\end{array}$ & $\begin{array}{c}\text { Probit } \\
\text { (e) }\end{array}$ \\
\hline Environmental tax & & $0.183^{\mathrm{a}}$ & $0.157^{\mathrm{a}}$ & $1.038^{\mathrm{a}}$ & $1.187^{\mathrm{a}}$ \\
\hline (\% of revenue) & & $(0.013)$ & $(0.023)$ & $(0.218)$ & $(0.272)$ \\
\hline \multirow[t]{2}{*}{ Number of tax bases } & & $0.021^{\mathrm{a}}$ & $0.019^{\mathrm{a}}$ & $0.444^{\mathrm{a}}$ & $0.521^{\mathrm{a}}$ \\
\hline & & $(0.002)$ & $(0.002)$ & $(0.067)$ & $(0.083)$ \\
\hline \multirow[t]{2}{*}{ Number of regulations } & & $0.031^{\mathrm{a}}$ & $0.065^{\mathrm{a}}$ & $1.541^{\mathrm{a}}$ & $1.731^{\mathrm{a}}$ \\
\hline & & $(0.118)$ & $(0.018)$ & $(0.373)$ & $(0.469)$ \\
\hline Share of waste management & $-10.639^{\mathrm{a}}$ & & $-4.193^{\mathrm{a}}$ & $-3.278^{b}$ & $-3.715^{\mathrm{b}}$ \\
\hline$\&$ recycling & $(1.107)$ & & $(1.341)$ & $(1.605)$ & $(2.022)$ \\
\hline \multirow[t]{2}{*}{ Interaction term ${ }^{*}$} & & & & $0.007^{\mathrm{a}}$ & $0.008^{\mathrm{a}}$ \\
\hline & & & & $(0.001)$ & $(0.008)$ \\
\hline \multirow[t]{2}{*}{ GDP per capita $(\$ 10000)$} & $0.114^{\mathrm{a}}$ & $0.306^{\mathrm{a}}$ & $0.278^{\mathrm{a}}$ & $0.211^{\mathrm{a}}$ & $0.274^{\mathrm{a}}$ \\
\hline & $(0.094)$ & $(0.021)$ & $(0.030)$ & $(0.034)$ & $(0.043)$ \\
\hline \multirow[t]{2}{*}{ Constant } & $-1.069^{\mathrm{a}}$ & $-3.771^{\mathrm{a}}$ & $-3.395^{\mathrm{a}}$ & $-11.409^{\mathrm{a}}$ & $-13.339^{\mathrm{a}}$ \\
\hline & $(0.078)$ & $(0.184)$ & $(0.293)$ & $(1.786)$ & $(2.220)$ \\
\hline Obs. & 13112 & 16189 & 13088 & 13088 & 13088 \\
\hline
\end{tabular}

